\title{
sciendo

\section{Production of Ligninolytic Enzymes by Coptotermes curvignathus Gut Bacteria}

\author{
Fadilah AYERONFE ${ }^{1}$, Angzzas KASSIM ${ }^{2 *}$, Patricia HUNG $^{3}$, Nadiah ISHAK $^{4}$, \\ Sharfina SYARIFAH ${ }^{5}$, Ashuvila ARIPIN ${ }^{6}$ \\ ${ }^{1,2,4-6}$ Department of Chemical Engineering Technology, Faculty of Engineering Technology, University \\ Tun Hussein Onn Malaysia, Batu Pahat, Johor, 86400, Malaysia \\ ${ }^{3}$ Department of Crop Science, Faculty of Agriculture and Food Sciences, University Putra Malaysia, \\ Bintulu, Sarawak, 97008, Malaysia
}

\begin{abstract}
Maximum utilization of lignocellulosic biomass is contingent upon degrading the recalcitrant lignin polymer. Conventional methods employed in delignification require high inputs of energy and chemicals, resulting in the release of highly toxic effluents. The ability of gut flora of Coptotermes curvignathus in lignin degradation was investigated in this study. Production of ligninolytic enzymes was done in an aerated submerged fermentation system with kraft lignin as sole carbon source. The degradation experiment was carried out for 7 days at $30^{\circ} \mathrm{C}, \mathrm{pH}$. Three potential lignin degraders identified as Bacillus sp., Lysinibacillus sp. and Acinetobacter sp. were successfully isolated. The bacterial growth and secretion of extracellular ligninolytic enzymes confirmed metabolism of kraft lignin by the identified strains. Lysinibacillus sp., a novel lignin degrader showed highest manganese peroxidase $(76.36 \pm 15.74 \mathrm{U} / \mathrm{L})$ and laccase activity $(70.67 \pm 16.82 \mathrm{U} / \mathrm{L})$ after 7 and 6 days of incubation respectively, while maximal activity of lignin peroxidase $(262.49 \pm 0.92 \mathrm{U} / \mathrm{L})$ was recorded after 7 days in culture supernatants of Bacillus $\mathrm{sp}$. With respect to the activity of the secreted enzymes, the lignin degrading potential of these bacterial strains can be explored in the valorisations of lignocellulosic biomass in industrial processes such as pulping, bioethanol production, fine chemicals and materials synthesis.
\end{abstract}

Keywords - Enzymes; kraft lignin; laccase; peroxidases; termites

\section{INTRODUCTION}

Termites thrive in great abundance in the terrestrial ecosystems and play a crucial role in depolymerization and mineralization of complex biopolymers in the tropics and subtropics [1], [2]. This is achieved by their highly specialized hind gut flora which produces acetate and other volatile fatty acids from the polysaccharide components and plant lignocelluloses complexes [1].

Lignin is an aromatic polymer of phenylpropanoid units which is found closely bound to hemicellulose and cellulose in the plant cell wall. It plays an important role in the transport of water and protection from pathogens [3], [4]. Lignin structural complexity, as well as its close association and chemical cross-linking with the carbohydrate fraction of plant cell wall makes enzymatic degradation difficult. Lignin biodegradation is a key step in the recycling of carbon in the ecosystem, and in the release of more easily degradable polysaccharides which can be utilized by other micro-organisms incapable of attacking the lignin component of wood [5]. Recently, there are significant interests in the biodegradation of lignin [6], as its

\footnotetext{
* Corresponding author.

E-mail address: angzzas@uthm.edu.my
}

(C)2019 Fadilah Ayeronfe, Angzzas Kassim, Patricia Hung, Nadiah Ishak, Sharfina Syarifah, Ashuvila Aripin.

This is an open access article licensed under the Creative Commons Attribution License (http://creativecommons.org/

licenses/by/4.0), in the manner agreed with Sciendo. 
presence impedes the maximum utilization of cellulose [7], [8] either for pulp or bioethanol production [9]-[11].

A controlled biocatalytic breakdown of lignin is also a potentially valuable source of renewable aromatic and phenolic bio-products, which would be valuable raw materials for the food and flavour industry, and for fine chemicals and materials synthesis [12]. Activity of microorganisms in lignin metabolism is one of the tenable evolutionary inceptions for the degradation of aromatic xenobiotics and environmental pollutants such as polychlorinated biphenyl.

Considerable efforts have been focused on ligninase enzymes production by white-rot and brown-rot fungi which are able to mineralize lignin. These fungi secrete a range of extracellular enzymes capable of degrading lignin which includes heme-dependent lignin peroxidases, manganese peroxidases, versatile peroxidases, and copper-dependent laccases [13]-[16]. However, long weeks of incubation and ligninase enzymes expression in fungi being a secondary metabolism have limited its commercial deployment [17].

Lignin modification by some Actinomycetes [18] and soil bacteria such as Norcadia, Rhodococcus and Pseudomonas sp. have also been reported [18], [19]. Ligninolytic bacteria, however, have not been extensively studied and, thus many ligninolytic enzymes may await discovery. Delignification by bacteria for biotechnological approach may offer several advantages over fungi in terms of large-scale growth efficiency, thermo stability and convenience in molecular genetics and protein expression [17], [20].

Coptotermes curvignathus is a common pest in Malaysia, notorious for its attack on rubber and oil palm plantations. The role of the gut flora of this termite in the degradation of cellulose has been investigated. However, no study has been carried out on the production of ligninase enzymes from the gut symbionts of Coptotermes curvignathus. This research, therefore, aims to screen and identify ligninolytic enzymes producing bacteria from the gut of Coptotermes curvignathus. The enzyme production was done in submerged fermentation system using kraft lignin as substrate.

\section{MATERIALS AND METHODS}

\subsection{Samples Collection and Preparation}

Bacteria isolates from termites' gut were obtained from the Department of Crop Science, University Putra Malaysia, Sarawak. The isolates were re-streaked on LB agar plates for $24 \mathrm{hrs}$ at $37^{\circ} \mathrm{C}$ and stored in $25 \%$ glycerol stock, prepared by mixing equal volumes of $50 \%$ glycerol and overnight cultures of the isolates, at $-70^{\circ} \mathrm{C}$.

\subsection{Screening of Lignin Degrading Bacteria}

The isolates were assayed for their lignin degrading capacity based on their ability to grow on Mineral salt media (MSM) supplemented with kraft lignin as sole carbon source, as well as their ability to decolorize commercialized dyes.

\subsubsection{Growth on MSM-Lignin Agar}

A selection protocol based on the ability to utilize kraft lignin as sole carbon source was used to select bacteria isolates capable of degrading lignin. MSM-Lignin agar was prepared according to Bandounas et al. [21] $200 \mathrm{~mL}$ M9 Salt solution $\left(64 \mathrm{~g} \mathrm{Na}_{2} \mathrm{HPO}_{4} .7 \mathrm{H}_{2} \mathrm{O}, 15 \mathrm{~g}\right.$

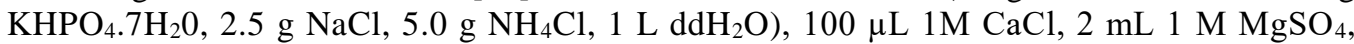
$5 \mathrm{~g}$ of lignin powder, $15 \mathrm{~g}$ of agar powder, $800 \mathrm{ml}$ of $\mathrm{ddH}_{2} \mathrm{O}$ and autoclaved at $120{ }^{\circ} \mathrm{C}$ for 
20 minutes. Formation of colonies was observed on MSM-Lignin agar plates incubated for 7 days at $37^{\circ} \mathrm{C}$.

\subsubsection{Dye Decolourization Assay of Isolates}

Decolorization of lignin-mimicking dyes has been reported to be evident of production of ligninolytic enzymes [19]. The isolates which showed good growth on MSM-Lignin agar were further screened for their ability to express ligninase enzymes using indicator dyes such as methylene blue and azure B as described by Bandounas et al. [21], colonies on MSMLignin agar were streaked on LB agar plates supplemented with $2 \mathrm{~g} / \mathrm{l}$ and $2 \mathrm{~g} / \mathrm{l}$ methylene blue and azure B respectively. The plates were incubated at $37{ }^{\circ} \mathrm{C}$ for $72 \mathrm{hrs}$ and observed for zone of clearance.

\subsection{Identification of Ligninolytic Enzyme-Producing Microorganisms}

The Microbial genomic DNA was extracted from the pure culture of selected bacterial isolates using DNeasy Qiagen Kit according to manufacturer's instruction. The 16S rRNA gene amplification and sequencing were carried out by First Base Laboratory, Malaysia. The PCR products were analysed on $0.8 \%(\mathrm{w} / \mathrm{v})$ agarose gel and sequenced. All sequences were blasted using BLAST against the NCBI 16S ribosomal RNA sequences (Bacteria only) Database, excluding uncultured Bacteria bacterium (taxid: 77133). Sequence data were aligned with software package MEGA and the Phylogenetic tree was constructed using the neighbour-joining method.

\subsection{Enzyme Production in Submerged Fermentation}

Production of ligninase enzymes was done via a continuous submerged fermentation system [22]. Kraft lignin degradation experiments were conducted under aerobic conditions at $30{ }^{\circ} \mathrm{C}$ pH 7 on a rotary shaker $(120 \mathrm{rpm})$ in LB medium supplemented with lignin as sole carbon source. The crude enzyme was extracted by centrifugation. The supernatant containing the crude enzyme extract was used to assay for enzymes activity, mentioned in 2.6.

\subsection{Bacterial Growth}

The growth rates of the isolates were determined by measuring the $\mathrm{OD}_{600}$ of cultured samples withdrawn at intervals. Centrifuged uninoculated medium was used as a control. The control and cultured samples were centrifuged at $5000 \mathrm{rpm}$ for $20 \mathrm{~min}$ to remove biomass and suspended solids. The supernatant containing the crude enzyme extract was used to assay for enzymes activity, mentioned in 2.6.

\subsection{Enzymes Assay}

Lignin peroxidase (LiP) activity was measured by monitoring the oxidation of veratryl alcohol to veratryl aldehyde in the presence of $\mathrm{H}_{2} \mathrm{O}_{2}$, this was determined by the increase in absorbance at $310 \mathrm{~nm}$. $\left(\varepsilon 310=9300 \mathrm{M}^{-1} \mathrm{~cm}^{-1}\right)$ in $100 \mathrm{mM}$ citrate buffer $\left(\mathrm{pH} \mathrm{3.0)}\right.$ at $30{ }^{\circ} \mathrm{C}$. Meanwhile, manganese peroxidase $(\mathrm{MnP})$ activity was assayed spectrophotometrically with phenol red $\left(\varepsilon 610=22000 \mathrm{M}^{-1} \mathrm{~cm}^{-1}\right)$ as substrate in $50 \mathrm{mM}$ sodium lactate at $(\mathrm{pH} 5.0) 30{ }^{\circ} \mathrm{C}$ [23]. Finally, laccase (Lac) activity was measured using 2,2-azinobis (3-ethylbenzthiazoline6- sulphonic acid) (ABTS) in $0.1 \mathrm{M}$ acetate buffer (pH4.5) at $30{ }^{\circ} \mathrm{C}$. Oxidation of ABTS was determined by the increase in A420 $\left(\varepsilon 420=36000 \mathrm{M}^{-1} \mathrm{~cm}^{-1}\right)$ [24]. The enzyme activity was expressed in international units (U), defined as the amount of enzyme required to convert $1 \mu$ mole of substrate to product per minute. 


\section{Statistical Analysis}

One-way analysis of variance (ANOVA) was carried out for the analysis. The results obtained and significant differences $(p<0.05)$ were determined using Minitab version 17.0.

\section{RESUlTS AND DisCUSSION}

\subsection{Screening of Lignin Degrading Microorganisms}

Aliquots of enrichment cultures were plated on MSM-lignin agar and further streaked on LB medium supplemented with lignin-mimicking dyes. Ten isolates out of 40 showed positive results for lignin degradation based on the qualitative screening on the selective agar and indicator dyes. This was evident based on the good growth observed on agar plates supplemented with kraft lignin as carbon source, as well as the formation of zone of clearance on methylene blue and azure b plates. The isolated were designated TG003, TG007, TG CH4, TG015, TG 016, TG 017, TG CH2, TG084, TG108, and TG101.

\subsection{Identification of Ligninolytic Microorganisms}

The ten selected isolates were identified from 16s RNA sequences. The phylogenetic analysis of the selected bacterial strains revealed that TG003, TG007, TG CH4, TG015, TG016, TG 017, TG CH2 formed a clade with Bacillus genus. TG084 was also shown to exhibit maximum homology with Lysinbacillus genus. Isolate TG 101 had previously been identified as Acinetobacter iwoffi. The isolates were therefore designated as Bacillus sp., Lysinbacillus sp. and Acinetobacter iwoffi respectively according to 16S rRNA gene identification.

The termite gut provides excellent habitat for lignocellulolytic microorganisms. These organisms produce acetate and other volatile fatty acids from the polysaccharide components and plant lignocelluloses complexes [1].

There are several reports on isolation of Bacillus species from termites' gut. Bacillus spp. have been identified in the gut of Zootermopsis angusticollis [25], [26], Odontermes sp. and Macrotermes sp. [27]. Cellulolytic Bacillus cereus has also been reported from the gut of Coptotermes curvignathus [28]. However, few reports on the lignin degradation capabilities of Bacillus species have been reported. Bandounas [21] reported the capability of Bacillus spp. to grow on kraft lignin and ligninolytic indicator dyes, with particular preference for recalcitrant phenothiazine dye class (Azure B, Methylene Blue and Toluidene Blue O). However, growth on kraft lignin was dependent on the incorporation of copper sulphate and yeast extract into the growth medium. This study reports the degradation of kraft lignin without the addition of co-substrates. Raj et al. [29] reported the ability of Bacillus spp. to decolourise kraft lignin after 6 days of incubation. This is consistent with the findings of this study.

There are no reports on the identification of Lysinbacillus spp. from termite's gut nor has the ligninolytic potential of this bacterial strains being reported. However, Lysinbacillus spp. were found to be present in dye contaminated soil [30], [31]. There are also reports of strains of Lysinbacillus sp. isolated from dye contaminated soil sample that are able to decolorize sulfonated azo dyes [32], [33] and industrial effluents [30]. This lends credence to the suggestion of a plausible link between aromatic degradation and lignin degradation [34], which is rational given that much of the aromatic material present in the soil are derivatives of lignin. 
Acinetobacter sp. has been isolated from the gut of wood and bark inhabiting long horned beetles [35], and also in the gut of Zootermopsis nevadensis [25]. Acinetobacter sp. has been also identified in a consortium reported to degrade $60.9 \%$ lignin in reeds within 15 days of cultivation. Acinetobacter sp. is clustered into the family of Gammaproteobacteria which is consistent with the classes of bacteria reported to be major lignin degraders; Alphaproteobacteria, Gammaproteobacteria and Actinobacteria [17]. Noteworthy, this observation suggests the existence of metabolic capabilities in these groups that aid in degradation of lignin. Degradation of biphenyl component of lignin has been reported in Acinetobacter and Bacillus genera [36]. Metabolism of this component is crucial in lignin degradation.

\subsection{Bacterial Growth}

In order to determine the lignin degrading capacity of the identified isolates, cultures of each strain were grown in LB medium supplemented with kraft lignin. Whilst, all strains showed good growth in kraft lignin without the addition of co-substrates, some strain grew much more swiftly than others (Fig. 1). This is an indication of the differences in the metabolism rate of kraft lignin exhibited by the isolates. Lysinbacillus sp. grew much more rapidly reaching optical density of 0.3 after $24 \mathrm{hrs}$ and 1.5 after $144 \mathrm{hrs}$, compared to Acinetobacter sp. (0.2 and 1.4) and Bacillus sp. (0.1 and 1.0) respectively. In contrast to the continual increase in cell density observed in culture of Acinetobacter sp. over the 7-day cultivation period, Lynsibacillus sp. and Bacillus sp. slowly decreased from a peak of 1.5 and 1.4 on day 6 to 1.4 and 1.3 respectively after 7 days of incubation. The decline in the cell density suggests the release of low weight molecular compounds which exhibit inhibitory effects on the growth of the bacterial strains.

\subsection{Enzymes Assay}

Extracellular peroxidases (lignin peroxidase, manganese peroxidase) and laccases which are the main ligninolytic enzymes have been characterized in microorganisms [4]. These enzymes show variations in characteristics with the microbial sources. The ability of an organism to produce either one or more of these enzymes also differs among microbes [37]. In this study, we investigated the ability of selected bacterial isolates in the production of LiP, MnP and laccase. Interestingly, activities of all three enzymes were detected in culture supernatants of all bacterial strains. This is consistent with a previous report on the biodegradation of kraft lignin by Comamonas sp. B-9 isolated from eroded bamboo slips [25]. However, ligninolytic enzyme systems reported in Pandoraea sp. B-6 isolated from bamboo slips lacked lignin peroxidase [38]. 


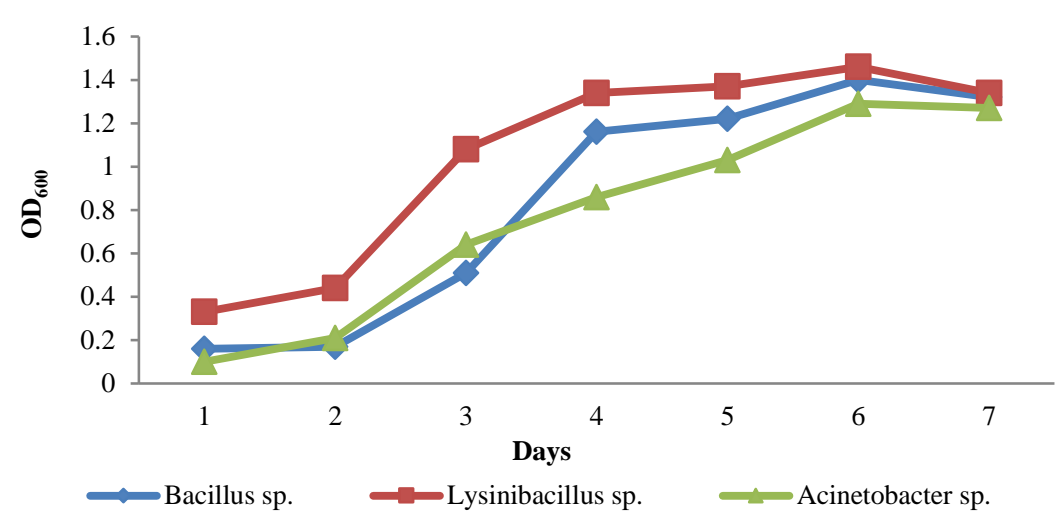

Fig. 1. Cell density $\left(\mathrm{OD}_{600}\right)$ of cultures of lignin-degrading gut isolates of Coptotermes curvignathus grown in LB medium supplemented with kraft lignin.

Table 1 show that maximum production of ligninolytic enzymes was reached on the 6th (LiP and Laccase) and $7^{\text {th }}$ day (MnP) of incubation. Peak LiP activity was reached on the 6th day of incubation during the production of ligninolytic enzymes from oil palm plantation soils [39]. This is consistent with the findings of this study. In contrast to MnP, LiP and laccase activities declined toward the 7th day of incubation. This could be explained by the accumulation of low molecular weight lignin fragments which exhibit inhibitory effects on enzyme productions [39]. However, low levels of MnP were detected in the initial $48 \mathrm{hrs}$ of incubation; it saw a significant increase after $72 \mathrm{hrs}$, and continually increasing through the following hours, reaching maximal after seven days of incubation (Fig. 2). It could be that the released low weight molecular compounds stimulated MnP production rather than inhibit as observed for LiP and laccase. Although, this is at variance with a previous study, where $\mathrm{MnP}$ activity was reported to significantly increase in the initial three days of incubation and declined through to the 7 th day of incubation. The disparity could be attributed to the variations in microbial sources and production parameters employed in both studies. The activity of ligninolytic enzymes is largely dependent on temperature, $\mathrm{pH}$ and presence of inducers [40].

Maximum LiP activity was recorded after 6 days of fermentation for Bacillus sp. $(247.52 \pm 4.8 \mathrm{U} / \mathrm{L})$ and $(262.49 \pm 0.92 \mathrm{U} / \mathrm{L})$ for Acinetacbacter sp. However, Lysinibacillus sp. reached peak activity (196.07 $\pm 1.43 \mathrm{U} / \mathrm{L})$ after 7 days of incubation. MnP peroxidase activity was the highest in culture supernatants of Lysinibacillus sp. (76.36 $\pm 15.74 \mathrm{U} / \mathrm{L})$, compared to that observed in Acinetobacter sp. (49.39 $\pm 5.50 \mathrm{U} / \mathrm{L})$ and Bacillus sp. (36.06 $\pm 1.462 \mathrm{U} / \mathrm{L})$ after 7 days. Optimal laccase activity was reached after 6 days with the highest activity recorded in Lysinibacillus sp. (70.67 $\pm 16.82 \mathrm{U} / \mathrm{L})$ and $(50.74 \pm 6.41 \mathrm{U} / \mathrm{L})$ for Acinetobacter sp., respectively. In comparison to all species, Bacillus sp showed the least laccase activity $(46.48 \pm 27.4 \mathrm{U} / \mathrm{L})$. 


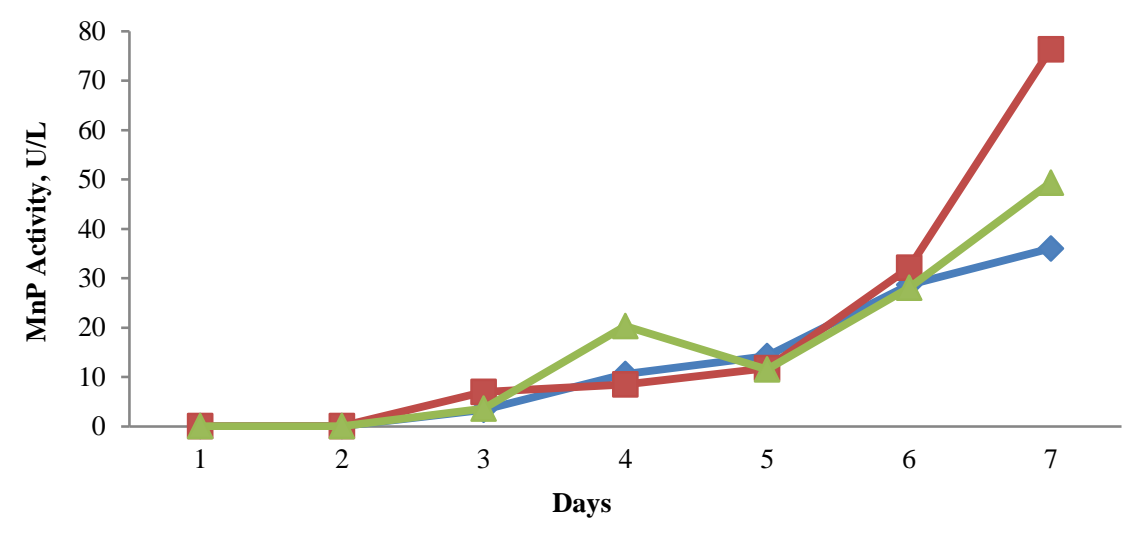

$\longrightarrow$ Bacillus sp. $\quad-$ Lysinibacillus sp. $\quad \longrightarrow$ Acinetobacter sp.

a)

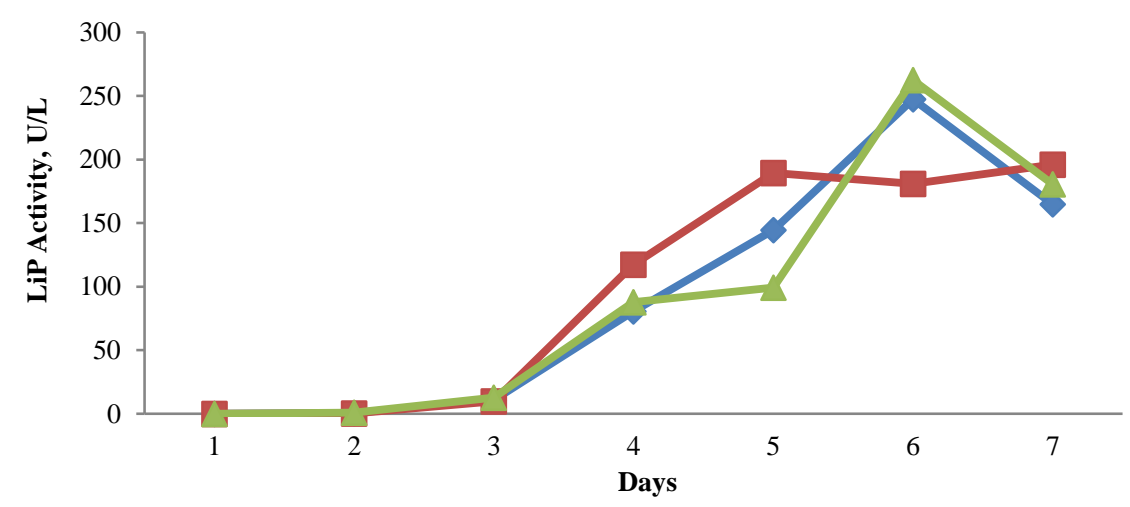

$\longrightarrow$ Bacillus sp. $\quad-$ Lysinibacillus sp. $\quad \longrightarrow$ Acinetobacter sp.

b)

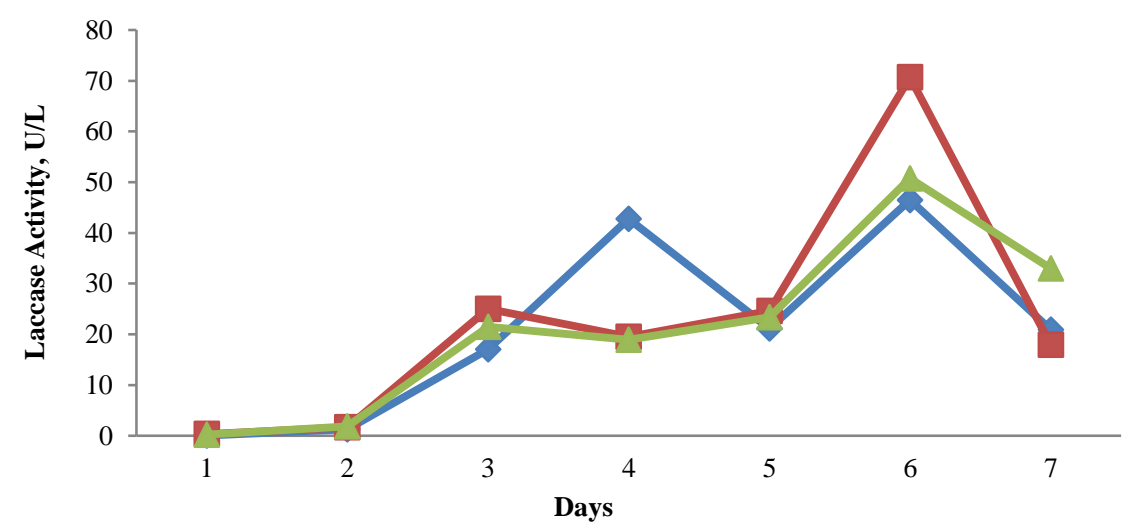

$\longrightarrow$ Bacillus sp. $\quad-$ Lysinibacillus sp. $\quad \longrightarrow$ Acinetobacter sp.

(c)

Fig. 2. Enzyme activities of a) MnP; b) LiP; c) Laccase during degradation of kraft lignin in submerged fermentation. 
TABle 1. Optimal ACTIVITY OF LigninOLYTIC ENZYMES SECRETED By the ISOLATES

\begin{tabular}{lllllll}
\hline Isolates & $\begin{array}{l}\text { Lignin peroxidase } \\
\text { Enzyme activity, U/L }\end{array}$ & Day & Enzyme activity, U/L & Day & $\begin{array}{l}\text { Enzyme } \\
\text { activity, U/L }\end{array}$ & \multicolumn{2}{c}{ Day } \\
\hline Bacillus sp. & $247.52 \pm 4.8$ & 6 & $36.06 \pm 1.462$ & 7 & $46.48 \pm 27.4$ & 5 \\
Lysinibacillus sp. & $196.07 \pm 1.43$ & 7 & $76.36 \pm 15.74 *$ & 7 & $70.67 \pm 16.82^{*}$ & 5 \\
Acinetobacter sp. & $262.49 \pm 0.92 *$ & 6 & $49.39 \pm 5.50$ & 7 & $50.74 \pm 6.41$ & 5 \\
\hline
\end{tabular}

*The highest species' enzyme activity.

Results indicate that activities of $\mathrm{LiP}(262.49 \pm 0.92 \mathrm{U} / \mathrm{L})$ was higher than that of MnP $(76.36 \pm 15.74 \mathrm{U} / \mathrm{L})$, as well as Laccase $(70.67 \pm 16.82 \mathrm{U} / \mathrm{L})$ in all isolates. This suggests that LiP could be the predominating enzyme in the ligninolytic enzyme systems of gut flora of Coptotermes curvignathus.

\section{Conclusions}

This study reports the lignin degrading capability of gut flora of Coptotermes curvignathus. Three bacteria isolates; two belonging to classes of previously known bacterial lignin degraders (Bacillus sp. and Acinetobacter sp.) and a novel lignin degrader (Lysinibacillus sp.) were identified. All bacterial strains were able to metabolise kraft lignin. However, Lysinibacillus sp. grew much more rapidly than others. Activities of all three enzymes were detected in culture supernatants of all bacterial strains studied. Lysinibacillus sp. showed optimal MnP and laccase activity, while highest LiP activity was observed in culture supernatant of Acinetobacter sp. The ability of the bacterial strains to produce LiP, MnP and laccase is advantageous for efficient delignification and can be explored for potential biotechnological applications in areas of pulping, bioremediation and bio-ethanol production. Not much is known about the novel Lysinibacillus sp. and further studies is required in order to explore the ligninolytic potential of this bacterium industrially. Optimization of the production parameters and purification of the secreted enzymes is also required to enabling better characterization of these enzymes and enhancing their activity.

\section{ACKNOWLEDGEMENT}

This research was financially supported by Ministry of Science Technology and Innovation (SO27). The authors like to thank technicians at the Department of Crop Science laboratory. We are thankful for their support.

\section{REFERENCES}

[1] Scharf M. E., Tartar A. A. Termite digestosomes as sources for novel lignocellulases. Biofuels Bioproducts and Biorefining 2008:2:540-552. doi:10.1002/bbb.107

[2] Jouquet P., Traoré S., Choosai C., Hartmann C., Bignell D. Influence of termites on ecosystem functioning. Ecosystem services provided by termites. European Journal of Soils Biology 2011:47(4):215-222. doi:10.1016/j.ejsobi.2011.05.005

[3] Crestini C., Crucianelli M., Orlandi M., Saladino R. Oxidative strategies in lignin chemistry: A new environmental friendly approach for the functionalisation of lignin and lignocellulosic fibers. Catalysis Today 2010:156(1-2):8-22. doi:10.1016/j.cattod.2010.03.057

[4] Pérez J., Muñoz-Dorado J., De La Rubia T., Martínez J. Biodegradation and biological treatments of cellulose, hemicellulose and lignin: An overview. International Microbiology 2002:5(2):53-63. doi:10.1007/s10123-002-0062-3

[5] Paliwal R., Rawat A. P., Rawat M., Rai J. P. N. Bioligninolysis: Recent updates for biotechnological solution. Applied Biochemisrty and Biotechnology 2012:167(7):1865-1889. doi:10.1007/s12010-012-9735-3 
[6] Kassim A. S. M., Ishak N., Aripin A. M., Zaidel D. N. Potential Lignin Degraders Isolated from the Gut of Rhynchophorus Ferrugineus. International Journal of Sustainable Construction Engineering \& Technology 2016:2(1):72-82. doi:10.2991/icmmse-16.2016.22

[7] Fisher A. B., Fong S. S. Lignin biodegradation and industrial implications. AIMS Bioengineering 2014:1(2):92-112. doi:10.3934/bioeng.2014.2.92

[8] Dashtban M., Schraft H., Syed T. A., Qin W. Fungal biodegradation and enzymatic modification of lignin. International Journal of Biochemisrty and Molecular Biology 2010:1(1):36-50.

[9] Kumar V., Singh S., Singh O. V. Bioconversion of lignocellulosic biomass: Biochemical and molecular perspectives. Journal of Industral Microbiology and Biotechnology 2008:35(5):377-391. doi:10.1007/s10295-008-0327-8

[10] Aunina Z., Bazbauers G., Valters K. Feasibility of Bioethanol Production From Lignocellulosic Biomass. Environmental and Climate Technologies 2010:4(1):11-5. doi:10.2478/v10145-010-0011-X

[11] Romagnoli F., Blumberga D., Gigli E. Biogas from marine macroalgae: a new environmental technology - life cycle inventory for a further LCA. Environmental and Climate Technologies 2010:4(1):97-108. doi:10.2478/v10145-010-0024-5

[12] Bugg T. D. H., Ahmad M., Hardiman E. M., Rahmanpour R. Pathways for degradation of lignin in bacteria and fungi. Natural Product Reports 2011:28(12):1883-1896. doi:10.1039/C1NP00042J

[13] Chi Y., Hatakka A., Maijala P. Can co-culturing of two white-rot fungi increase lignin degradation and the production of lignin-degrading enzymes? International Biodeterioration \& Biodegradation 2007:59(1):32-39. doi:10.1016/j.ibiod.2006.06.025

[14] Tuor U., Winterhalter K., Fiechter A. Enzymes of white-rot fungi involved in lignin degradation and ecological determinants for wood decay. Journal of Biotechnology 1995:41(1):1-17. doi:10.1016/0168-1656(95)00042-O

[15] Fackler K., Gradinger C., Hinterstoisser B., Messner K., Schwanninger M. Lignin degradation by white rot fungi on spruce wood shavings during short-time solid-state fermentations monitored by near infrared spectroscopy. Enzyme and Microbial Technology 2006:39(7):1476-1483. doi:10.1016/j.enzmictec.2006.03.043

[16] Singh P., Sulaiman O., Hashim R., Rupani P. F., Peng L. C. Biopulping of lignocellulosic material using different fungal species: A review. Reviews in Environmental cience and Bio/Technology 2010:9(2):141-151. doi:10.1007/s11157-010-9200-0

[17] Bugg T. D. H., Ahmad M., Hardiman E. M., Singh R. The emerging role for bacteria in lignin degradation and bioproduct formation. Current Opinion in Biotechnology 2011:22(3):394-400.

[18] Zimmermann W. Degradation of lignin by bacteria. Journal of Biotechnology 1990:13(2-3):119-130. doi:10.1016/0168-1656(90)90098-V

[19] Ahmad M., Taylor C. R., Pink D., Burton K., Eastwood D., Bending G. D., Bugg T. D. Development of novel assays for lignin degradation: comparative analysis of bacterial and fungal lignin degraders. Molecular BioSystems 2010:6(5):815-821. doi:10.1039/b908966g

[20] Niladevi K. N., Jacob N., Prema P. Evidence for a halotolerant-alkaline laccase in Streptomyces psammoticus: Purification and characterization. Process Biochemistry 2008:43(6):654-660. doi:10.1016/j.procbio.2008.02.002

[21] Bandounas L., Wierckx N. J., De Winde J. H., Ruijssenaars H. J. Isolation and characterization of novel bacterial strains exhibiting ligninolytic potential. BMC Biotechnology 2011:11(1):94. doi:10.1186/1472-6750-11-94

[22] Erden E., Ucar M. C., Gezer T., Pazarlioglu N. K. Screening for ligninolytic enzymes from autochthonous fungi and applications for decolorization of Remazole Marine Blue. Brazilian Journal of Microbioloy 2009:40:346-353. doi:10.1590/S1517-838220090002000026

[23] Obruca S. Marova I., Matouskova P., Haronikova A., Lichnova A. Production of lignocellulose-degrading enzymes employing Fusarium solani F-552. Folia Microbiologica 2012:57:221-227. doi:10.1007/s12223-012-0098-5

[24] Chen Y. H., Chai L. Y., Zhu Y. H., Yang Z. H., Zheng Y., Zhang H. Biodegradation of kraft lignin by a bacterial strain Comamonas sp. B-9 isolated from eroded bamboo slips. Journal of Applied Microbiology 2012:112(5):900-906. doi:10.1111/j.1365-2672.2012.05275.x

[25] Schäfer A., Konrad R., Kuhnigk T., Kämpfer P., Hertel H., König H. Hemicellulose-degrading bacteria and yeasts from the termite gut. Journal of Applied Bacteriology 1996:80(5):471-478. doi:10.1111/j.1365-2672.1996.tb03245.x

[26] Wenzel M., Schönig I., Berchtold M., Kämpfer P., König H. Aerobic and facultatively anaerobic cellulolytic bacteria from the gut of the termite Zootermopsis angusticollis. Journal of Applied Microbiology 2002:92(1):32-40. doi:10.1046/j.1365-2672.2002.01502.x

[27] Muwawa E. M., Budambula N. L. M., Osiemo Z. L., Boga H. I., Makonde H. M. Isolation and characterization of some gut microbial symbionts from fungus-cultivating termites (Macrotermes and Odontotermes spp.). African Journal of Microbiology Research 2016:10(26):994-1004.

[28] Ramin M., Alimon A. R., Abdullah N. Identification of cellulolytic bacteria isolated from the termite coptotermes curvignathus (Holmgren). Journal of Rapid Methods Automotion in Microbiology 2009:17(1):103-116. doi:10.1111/j.1745-4581.2009.00160.x

[29] Raj A., Krishna Reddy M. M., Chandra R.. Identification of low molecular weight aromatic compounds by gas chromatography-mass spectrometry (GC-MS) from kraft lignin degradation by three Bacillus sp. International Biodeterioration \& Biodegradation 2007:59(4):292-296. doi:10.1016/j.ibiod.2006.09.006 
[30] Anjaneya O., Souche S. Y., Santoshkumar M., Karegoudar T. B. Decolorization of sulfonated azo dye Metanil Yellow by newly isolated bacterial strains: Bacillus sp. strain AK1 and Lysinibacillus sp. strain AK2. Journal of Hazardous Materials 2011:190(1-3):351-358. doi:10.1016/j.jhazmat.2011.03.044

[31] Liang B., Lu P., Li, H. Li R., Li S., Huang X. Chemosphere Biodegradation of fomesafen by strain Lysinibacillus sp. ZB-1 isolated from soil. Chemosphere 2009:77(11):1614-1619. doi:10.1016/j.chemosphere.2009.09.033

[32] Chaudhari A. U., Tapase S. R., Markad V. L., Kodam K. M. Simultaneous decolorization of reactive Orange M2R dye and reduction of chromate by Lysinibacillus sp. KMK-A. Journal of Hazardous Materials 2013:262:580-588 doi:10.1016/j.jhazmat.2013.09.006

[33] Saratale R. G., et al. Decolorization and detoxi fi cation of sulfonated azo dye C . I . Remazol Red and textile effluent by isolated Lysinibacillus sp. RGS. Journal of Bioscience and Bioengineering 2013:115(6):658-667. doi:10.1016/i.jbiosc.2012.12.009

[34] Taylor C. R., Hardiman E. M, Ahmad M., Sainsbury P. D., Norris P. R., Bugg T. D. H. Isolation of bacterial strains able to metabolize lignin from screening of environmental samples. Journal of Applied Microbiology 2012:113(3):521-530. doi:10.1111/j.1365-2672.2012.05352.x

[35] Grunwald S., Pilhofer M., Hol, L1 W. Microbial associations in gut systems of wood- and bark-inhabiting longhorned beetles [Coleoptera: Cerambycidae]. Systematic and Applied Microbiology 2010:33(1):25-34. doi:10.1016/j.syapm.2009.10.002

[36] Pieper D. H. Aerobic degradation of polychlorinated biphenyls. Applied Microbiology and Biotechnology 2005:67(2):170-191. doi:10.1007/s00253-004-1810-4

[37] Hakala T. K., Lundell T., Galkin S., Maijala P., Kalkkinen N., Hatakka A. Manganese peroxidases, laccases and oxalic acid from the selective white-rot fungus Physisporinus rivulosus grown on spruce wood chips. Enzyme and Microbial Technology 2005:36(4):461-468. doi:10.1016/j.enzmictec.2004.10.004

[38] Shi Y., Chai L., Tang C., Yang Z., Zheng Y., Chen Y., Jing Q. Biochemical investigation of kraft lignin degradation by pandoraea sp. B-6 isolated from bamboo slips. Bioprocess Biosystems Engineering 2013:36(12):1957-1965. doi:10.1007/s00449-013-0972-9

[39] Hashimah N., Rahman A, Aini N., Rahman A., Aziz S. A., Hassan M. A. Production of Ligninolytic Enzymes by Newly Isolated Bacteria from Palm Oil Plantation Soils. Bioresources 2013:8:6136-6150.

[40] Liew C. Y., Husaini A., Hussain H., Muid , Liew K. C., Roslan H. A. Lignin biodegradation and ligninolytic enzyme studies during biopulping of Acacia mangium wood chips by tropical white rot fungi. World Journal of Microbiology and Biotechnology 2011:27(6):1457-1468. doi:10.1007/s11274-010-0598-x

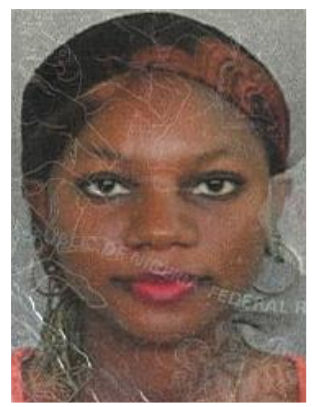

Fadilah Ayeronfe was born in Lagos, Nigeria. She completed her secondary education at Archbishop Aggey Memorial Secondary School, Lagos Nigeria, in 2005. She proceeded to obtaining a Bachelor's of Science degree at the University of Ilorin, Ilorin, Nigeria in 2007 and graduated with a second-class upper division in microbiology in 2011. The author continued her academics at the University Tun Husein Onn Malaysia (UTHM) from 20162018 as a graduate and currently awaiting viva voce for the award of Master in Engineering Technology.

She was a Graduate Research Assistant with the Department of Chemical Engineering Technology, Faculty of Engineering Technology at UTHM from 2016-2017. She worked as an Administrative Officer at the Local Government Secretariat, Ondo state, Nigeria from 2011-2012. Her research interests are: Production of ligninolytic enzymes from termite's gut bacteria; The discovery of aromatic degrading enzymes from lignocellulolytic biomass; Turnover of pollutants and the production of high value novel compounds by microorganism; Anti-microbial drug discovery for innovative applications. The author received a silver medal at the Research and Innovation Festival, 2016 from UTHM, Malaysia.

ORCID ID: https://orcid.org/0000-0002-9918-131X

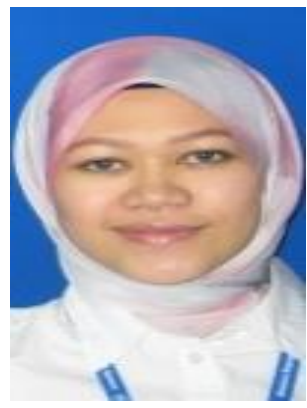

Angzzas Kassim received the Bachelor degree in chemical engineering from University of Manchester Institute of Science and Technology, UK in 2003. She continued her studies at University of Strathclyde and received the Doctoral degree in plant biotechnology in 2008. She was conferred the title of Associate Professor in 2016.

She is the Deputy Dean (Academics and International) of the Faculty of Engineering Technology (FTK) from 2017 till date. She was previously appointed the Head of Department of Chemical Engineering, FTK in 2013. She also contributed in laboratory set up for the department during her appointment as the Head of Laboratory from 2010-2013. Her research interests are: Biodelignification of oil palm residues for pulp and paper production; Enzyme technology; Molecular marker; Bioprocessing and Biotechnology.

The author has several articles published in ISI indexed journals as well as in Scopus indexed journals. The author is an associate member of the Institution of Chemical engineers 
(IChemE). She has received a number of research grants and had gained both national and international recognitions over the years. ORCID ID: https://orcid.org/0000-0002-7519-0019

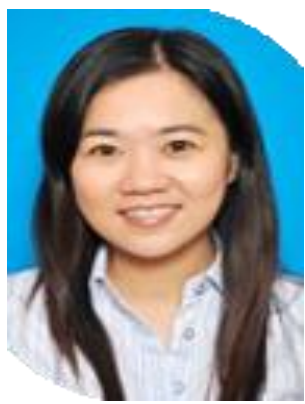

Patricia Hung received the Bachelor of Science degree in microbiology from Universiti Kebangsaan Malaysia in 1998. She continued her studies at the same University and received the Master of Science and the Doctoral degree in microbiology in 2001 and 2009 respectively. She was conferred the title of Associate Professor in 2016.

She is a Senior lecturer at Universiti Putra Malaysia, Bintulu Sarawak Campus from 2010 till date. She was previously a lecturer at the same university from 2002-2010. Her research interests are:

- Host-Microbial Interaction with special focus on functional genes based on Metagenomics and Trancriptomics Approach;

- Anti-inflammatory and anti-oxidant properties of plant extracts and refined palm oil;

- Pest and disease management for oil palm plantation and black pepper farms;

- Zero waste oil palm industry (waste to wealth).

The author has several articles published in ISI indexed journals as well as in Scopus indexed journals. She has received a number of research grants and had gained both national and international recognitions over the years.

ORCID: http://orcid.org/0000-0003-4522-0165

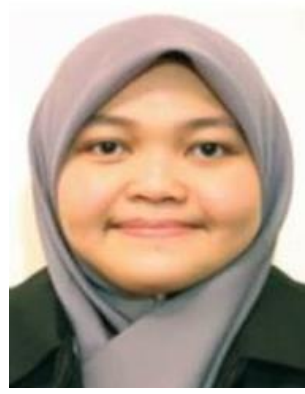

received a silver medal.
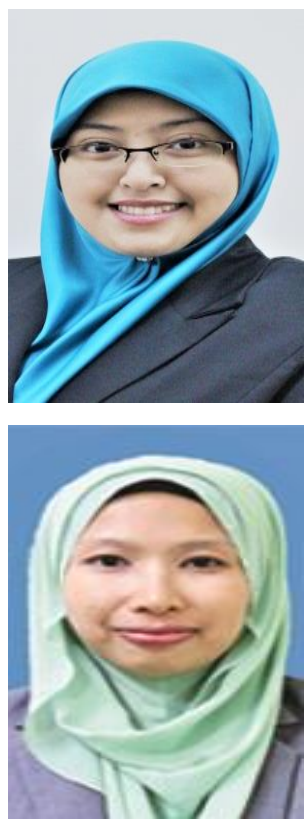

Nadiah Ishak was born in November 2, 1989, in Johor Bahru, Malaysia. She completed her degree at University of Adelaide, Australia and graduated with the Bachelor of Science (biotechnology) in 2011. The author was awarded the Master of Biotechnology with specialization in biomedical and bioinformatics system at University of Adelaide, Australia. She received the Ph. D. in Engineering Technology in 2018 at University Tun Hussein Onn Malaysia (UTHM), Malaysia.

She completed an internship at Australian Centre of Plant of Functional Genomics (ACPFG), Australia. The author has published two papers and co-authored seven papers in the field of Microbiology, Material Engineering and Applied Science. Her research interests are in the areas of biotechnology and chemical engineering.

She received a Ph. D. Scholarship (My brain Malaysia) in 2014 and was awarded a bronze medal at the 3-minute thesis competition, organized by UTHM, in 2016. The author also participated in the Research and innovation festival organized by UTHM in 2016 where she

Sharfina Syarifah received the Bachelor of Science (Hons) resource biotechnology from University of Malaysia Sarawak in 2016. She is currently in her second year of Master studies in the department of Chemical Engineering, Faculty of Engineering Technology, and University Tun Hussein Onn Malaysia.

She is currently a graduate research assistant in the department of Chemical Engineering, Faculty of Engineering Technology, and University Tun Hussein Onn Malaysia. She also volunteered in the research group for postgraduates, under the Association of Student Chapters, aimed at organizing research related events. Her research interest is in the evaluation of biomechanical process in paper making using termites ' gut bacteria.

Ashuvila Aripin received a Diploma in Science (Physics) in 2008 and a Bachelor of Science (Hons) environmental technology in 2011 at the University Teknologi MARA, Malaysia She pursued her Master studies in University Tun Hussein Onn Malaysia and was awarded the Master of Science in 2014. She is currently a doctoral candidate in the Faculty of Engineering Technology, University Tun Hussein Onn Malaysia.

She was a Graduate Research Assistant in the department of Chemical Engineering, Faculty of Engineering Technology, University Tun Hussein Onn Malaysia from 2012-2014. Her research interest is on the optimization of Sago worm bacteria for biomechanical pulping process on empty fruit bunch of oil palm biomass. bioprocessing and bio-pulping.

She has a number of articles published in ISI indexed journals as well as in Scopus indexed journals. She was a recipient of the My Brain Malaysia Ph. D. Scholarship. 